\title{
FAKTOR-FAKTOR YANG BERHUBUNGAN DENGAN KEJADIAN HIPEREMESIS GRAVIDARUM PADA IBU HAMIL TRIMESTER PERTAMA DI WILAYAH PUSKESMAS TANJUNG PASIR 2020
}

\author{
BASYARIAH LUBIS, ${ }^{1}$ LATIFAH HANIM ${ }^{2}$, SRIMELDA BR BANGUN ${ }^{3}$, \\ RONNY AJARTHA 4
}

\author{
FAKULTAS KEBIDANAN INSTITUT KESEHATAN MEDISTRA \\ JL. SUDIRMAN NO. 38 LUBUK PAKAM KEC LUBUK PAKAM \\ KAB DELI SERDANG \\ Email: basyariahlubis@gmail.com \\ DOI $10.35451 / \mathrm{jkg} . \mathrm{v} 3 \mathrm{i} 2.533$
}

\begin{abstract}
Abstrak
The incidence of hyperemesis gravidarum in Indonesia ranges from $1 \%$ to $3 \%$ of all pregnancies. Hyperemesis gravidarum can cause problems in pregnancy such as anemia, while anemia itself can result in shock due to lack of nutritional intake, all of which are eaten and drunk. This study aims to determine the relationship between adaptation and psychological factors with the incidence of hyperemesis gravidarum in pregnant women in the first trimester in the Tanjung Pasir Health Center area.

This research is an analytical survey with a cross sectional approach. The study was conducted in the Tanjung Pasir 2020 Public Health Center area from March to August 2020. The population in this study were 108 pregnant women in the first trimester at the Hamidah Clinic and a sample of 52 people. Data were obtained using a questionnaire, data analysis consisted of univariate and bivariate analysis. Bivariate analysis using the Chi Square statistical test at $a=$ $5 \%$.

The results showed that there was no relationship between adaftation factors (anemia and primigravida) with hyperemesis gravidarum, while psychological factors (unwanted pregnancy, work pressure, income and family harmony) had a relationship with hyperemesis gravidarum.

The conclusion of this study is there is a relationship between psychological factors and the incidence of hyperemesis gravidarum in pregnant women in the first trimester in the Tanjung Pasir Puskesmas area. It is suggested that the respondents should increase their knowledge about how to prevent and overcome hyperemesis gravidarum.
\end{abstract}

Keywords : Adaftasi, Psychological, Hyperemesis Gravidarum

\section{PENDAHULUAN}

Angka kejadian hyperemesis gravidarum sudah mendunia dengan angka kejadian yang beragam mulai dari Negara Amerika angka prevalensi mencapai $2 \%$, Turki 1,9\%, California $0,5 \%$, Swedia 0,9\% dan Indonesia angka kejadian mencapai $1-3 \%$ dari seluruh jumlah kehamilan angka kejadian hyperemesis gravidarum ini terus meningkat hingga mencapai 15\% (APN, 2017). Tanda gelaja seperti mual dan muntah merupakan masalah yang paling sering ditemui pada awal-awal kehamilan, sebagian besar ibu hamil mengatakan bahwa 
gejala mual dan muntah sering terjadi pada wanita primigravida.

Tetapi kalau seorang ibu memuntahkan semua yang di konsumsi baik jenis makanan dan minuman yang mengakibatkan berat badan ibu semangkin menurun dan ditandai dengan peningkatan asam lambung yang berlebihan sehingga mual dan muntah yang ibu hamil alami akan terus memperburuk keadaan kehamilannya (Saifuddin, 2015). Hiperemesis gravidarum merupakan gejala mual muntah berat yang terjadi selama kehamilan yang menyebabkan penurunan berat badan $>3 \mathrm{~kg}$ atau $>5 \mathrm{~kg}$ dari berat badan sebelum kehamilan sehingga membutuhkan nutrisi parental dan perawatan. Keluhan ini juga dapat menyebabkan dehidrasi, gangguan keseimbangan metabolit dan elektrolit (hipokalemia), defisiensi nutrisi, dan ketonuria. Bahkan jika tidak ditangani dapat mengakibatkan robekan pada esophagus, Wernicke ensefalopathi, kerusakan hati dan ginjal, dan kematian (Amiruddin, 2015). Pencegahan terhadap hyperemesis gravidarum dapat di cegah dengan cara mengedukasi dan memberikan informasi tentang hyperemesis gravidarum pada ibu-ibu hamil dengan maksud merubah konsep berfikir dengan tujuan menghilangkan faktor psikis seperti rasa takut serta memberikan penjelasan pada ibu hamil bahwa mual dan muntah merupakan gejala fsikologis pada awal kehamilan dan akan hilang setelah kehamilan 4 bulan. Menganjurkan makan sedikit tetapi sering, menyajikan makan sebaiknya dalam keadaan hangat, menghindari jenis konsumsi makanan yang berminyak dan berlemak, dan menganjurkan ibu untuk tidak segera turun dari tempat tidur saat bangun pagi tetapi usahakan mengkonsumsi roti kering atau biscuit dan teh hangat terlebih dahulu (Elsa, 2012).

Hiperemesis Gravidarum dapat memunculkan kondisi yang membawa dampak pada setiap ibu hamil seperti morning sickness yang ekstrem pada masa kemilan dan di tandai dengan mual muntah yang parah. Sehingga ibu mengalami penurunan nafsu makan yang menyebabkan perubahan keseimbangan elektrolit yakni kalium, dan natrium sehingga mengakibatkan ibu hamil mengalami perubahan metabolisme dalam tubuh. Efek lain dari hyperemesis gravidarum dapat berupa penurunan berat badan yang di karenakan cadangan protein, lemak dan karbohidrat terpakai energy selama ibu mengalami mual dan muntah (Kusmiati, 2017). Akibat dari hiperemesis gravidarum bukan hanya mengganggu kesehatan ibu selama kehamilan akan tetapi dapat juga menyebabkan dampak lain seperti bayi lahir kurang bulan (premature), berat badan lahir rendah, abortus, serta malformasi pada bayi baru lahir (Elsa, 2017).

Selain adaptasi ibu hamil pada keadaan fisiologis ibu hamil memang selalu mengalami mual dan muntah tetapi mual dan muntah tersebut akan diperparah apabila ibu hamil juga mengalami gangguan psikologis seperti ibu mengalami kecemasan yang berlebihan serta stress emosional. Ketika istri mengalami stress pada kehamilannya akan berpengaruh pada suami, karena suami merupakan orang terdekat bagi istri. Selama kehamilan seorang istri sangat menginginkan perhatian yang lebih dari pendamping/suami. Dimana suami di harapkan bisa membantu dan menjaga istri dalam mengatasi masalah-masalah selama dalam kehamilan sehingga istri dapat merasa lebih tenang dan nyaman bersama sibuah hati yang mereka inginkan. Mual muntah pada masa 
kehamilan yang terus berlanjut maka akan berdampak buruk bagi ibu dan bayinya serta dapat mengganggu aktivitas ibu sehari-hari. Berdasarkan survey awal di Puskesmas Tanjung Pasir Kab. Labuhan Batu Utara jumlah ibu hamil yang memeriksakan kehamilannya pada bulan OktoberDesember 2020 sebanyak 250 orang dari data yang didapat mengalami hyperemesis gravidarum sebanyak 50 orang. Berdasarkan data dari latar belakang atas maka penulis tertarik untuk meneliti mengenai "Faktor Yang Berhubungan dengan hyperemesis gravidarum pada ibu hamil trimester pertama di Puskesmas Tanjung Pasir Kab. Labuhan Batu Utara".

\section{METODE PENELITIAN}

Jenis penelitian yang digunakan dalam penelitian ini merupakan observasional analitik dengan pendekatan cross sectional untuk mempelajari hubungan antara variabel bebas (independent) dan variabel (dependent). Pada penelitian ini faktor adaftasi dan faktor psikologis pada saat hamil sebagai variable independent dan kejadian hyperemesis gravidarum sebagai variabel dependent yang dilakukan pengukuran secara bersamaan (Prawihardjo, 2017). Lokasi Penelitian ini dilakukan di Puskesmas Tanjung Pasir Kab. Labuhan Batu Utara. Waktu penelitian dimulai dari bulan FebruariJuli 2020. Pengambilan sampel dilakukan dengan menggunakan simple random sampling dengan jumlah sampel 52 orang.

\section{HASIL DAN PEMBAHASAN}

Setelah dilakukan penelitian tentang hubungan faktor adaftasi dan faktor psikologis dengan kejadian hyperemesis gravidarum pada ibu hamil trimester pertama di Puskesmas Tanjung Pasir Kab.
Labuhan Batu Utara, data yang diperoleh sebagai berikut :

Tabel 1. Hubungan Anemia Dengan Kejadian Hiperemesis Gravidarum di Puskesmas Tanjung Pasir Kab. Labuhan Batu Utara

\begin{tabular}{|c|c|c|c|c|c|c|c|c|}
\hline \multirow{3}{*}{$\begin{array}{l}\mathbf{N} \\
\mathbf{0}\end{array}$} & \multirow{3}{*}{$\begin{array}{l}\text { An } \\
\text { em } \\
\text { ia }\end{array}$} & \multicolumn{4}{|c|}{$\begin{array}{l}\text { Kejadian } \\
\text { Hiperemesis } \\
\text { Gravidarum }\end{array}$} & \multirow{2}{*}{\multicolumn{2}{|c|}{$\begin{array}{l}\text { Juml } \\
\text { ah }\end{array}$}} & \multirow{3}{*}{$\begin{array}{l}p- \\
\text { va } \\
\text { lu } \\
e\end{array}$} \\
\hline & & \multicolumn{2}{|c|}{$\begin{array}{l}\text { Tidak } \\
\text { Hipere } \\
\text { mesis } \\
\text { Gravid } \\
\text { arum }\end{array}$} & \multicolumn{2}{|c|}{$\begin{array}{l}\text { Hipere } \\
\text { mesis } \\
\text { Gravid } \\
\text { arum }\end{array}$} & & & \\
\hline & & $\mathbf{F}$ & $\%$ & $\mathbf{F}$ & $\%$ & $\mathbf{F}$ & $\%$ & \\
\hline 1 & $\begin{array}{l}\text { Tid } \\
\text { ak } \\
\text { Ane } \\
\text { mia }\end{array}$ & $\begin{array}{l}1 \\
7\end{array}$ & $\begin{array}{l}32 \\
.7\end{array}$ & $\begin{array}{l}1 \\
9\end{array}$ & $\begin{array}{l}36 \\
.5\end{array}$ & $\begin{array}{l}3 \\
6\end{array}$ & $\begin{array}{l}6 \\
9 . \\
2\end{array}$ & 0 \\
\hline 2 & $\begin{array}{l}\text { Ane } \\
\text { mia } \\
\text { Rin } \\
\text { gan }\end{array}$ & 7 & $\begin{array}{l}13 \\
.5\end{array}$ & 6 & $\begin{array}{l}11 \\
.5\end{array}$ & $\begin{array}{l}1 \\
3\end{array}$ & $\begin{array}{l}2 \\
5 . \\
0\end{array}$ & $\begin{array}{l}80 \\
0\end{array}$ \\
\hline 3 & $\begin{array}{l}\text { Ane } \\
\text { mia } \\
\text { Sed } \\
\text { ang }\end{array}$ & 1 & $\begin{array}{l}1 . \\
9\end{array}$ & 2 & $\begin{array}{l}3 . \\
8\end{array}$ & 3 & $\begin{array}{l}5 . \\
8\end{array}$ & \\
\hline \multicolumn{2}{|c|}{ Total } & $\begin{array}{l}2 \\
5\end{array}$ & $\begin{array}{l}48 \\
.1\end{array}$ & $\begin{array}{l}2 \\
7\end{array}$ & $\begin{array}{l}51 \\
.9\end{array}$ & $\begin{array}{l}5 \\
2\end{array}$ & $\begin{array}{l}1 \\
0 \\
0\end{array}$ & \\
\hline
\end{tabular}

Hasil uji statistik dengan menggunakan uji chi square, diperoleh hasil perhitungan $p$ value $=$ $0,800>0,05$, maka Ha ditolak. Kesimpulannya Tidak Ada Hubungan Anemia dengan kejadian hiperemesis gravidarum pada ibu hamil trimester pertama di Puskesmas Tanjung Pasir Kab. Labuhan Batu Utara.

Tabel 2. Hubungan Gravida Dengan Kejadian Hiperemesis Gravidarum di Puskesmas Tanjung Pasir Kab. Labuhan Batu Utara

\begin{tabular}{|c|c|c|c|c|c|c|c|c|}
\hline \multirow{3}{*}{$\begin{array}{l}\mathbf{N} \\
\mathbf{0}\end{array}$} & \multirow{3}{*}{$\begin{array}{l}\text { Grav } \\
\text { ida }\end{array}$} & \multicolumn{4}{|c|}{$\begin{array}{l}\text { Kejadian } \\
\text { Hiperemesis } \\
\text { Gravidarum }\end{array}$} & \multirow{2}{*}{\multicolumn{2}{|c|}{$\begin{array}{l}\text { Juml } \\
\text { ah }\end{array}$}} & \multirow{3}{*}{$\begin{array}{l}p- \\
\text { va } \\
\text { lu } \\
e\end{array}$} \\
\hline & & \multicolumn{2}{|c|}{$\begin{array}{l}\text { Tidak } \\
\text { Hipere } \\
\text { mesis } \\
\text { Gravid } \\
\text { arum }\end{array}$} & \multicolumn{2}{|c|}{$\begin{array}{l}\text { Hipere } \\
\text { mesis } \\
\text { Gravid } \\
\text { arum }\end{array}$} & & & \\
\hline & & $\mathbf{F}$ & $\%$ & $\mathbf{F}$ & $\%$ & $\mathbf{F}$ & $\%$ & \\
\hline 1 & $\begin{array}{l}\text { Tidak } \\
\text { Primi } \\
\text { gravi } \\
\text { da }\end{array}$ & 8 & $\begin{array}{l}15 \\
.4\end{array}$ & $\begin{array}{l}1 \\
3\end{array}$ & $\begin{array}{l}25 \\
.0\end{array}$ & $\begin{array}{l}2 \\
1\end{array}$ & $\begin{array}{l}4 \\
0 . \\
4\end{array}$ & $\begin{array}{l}0 \\
27 \\
0\end{array}$ \\
\hline
\end{tabular}




\begin{tabular}{|c|c|c|c|c|c|c|c|}
\hline 2 & $\begin{array}{l}\text { Primi } \\
\text { gravi } \\
\text { da }\end{array}$ & $\begin{array}{l}1 \\
7\end{array}$ & $\begin{array}{l}32 \\
.7\end{array}$ & $\begin{array}{l}1 \\
4\end{array}$ & $\begin{array}{l}26 \\
.9\end{array}$ & $\begin{array}{l}3 \\
1\end{array}$ & $\begin{array}{l}5 \\
9 . \\
6\end{array}$ \\
\hline & & $\begin{array}{l}2 \\
5\end{array}$ & $\begin{array}{l}4 \\
8 . \\
1\end{array}$ & $\begin{array}{l}2 \\
7\end{array}$ & $\begin{array}{l}5 \\
1 . \\
9\end{array}$ & $\begin{array}{l}5 \\
2\end{array}$ & $\begin{array}{l}1 \\
0 \\
0\end{array}$ \\
\hline
\end{tabular}

Hasil uji statistik dengan menggunakan uji chi square, diperoleh hasil perhitungan $p$ value $=$ $0,27>0,05$, maka $\mathrm{Ha}$ ditolak. Kesimpulannya Tidak Ada Hubungan gravida dengan kejadian hiperemesis gravidarum pada ibu hamil trimester pertama di Puskesmas Tanjung Pasir Kab. Labuhan Batu Utara.

Tabel 3. Hubungan Kehamilan Tidak Diinginkan Dengan Kejadian Hiperemesis Gravidarum di Puskesmas Tanjung Pasir Kab. Labuhan Batu Utara

\begin{tabular}{|c|c|c|c|c|c|c|c|c|}
\hline \multirow{3}{*}{$\begin{array}{l}\mathbf{N} \\
\mathbf{O}\end{array}$} & \multirow{3}{*}{$\begin{array}{l}\text { Keh } \\
\text { amil } \\
\text { an } \\
\text { Tida } \\
\text { k } \\
\text { Diin } \\
\text { gink } \\
\text { an }\end{array}$} & \multicolumn{4}{|c|}{$\begin{array}{l}\text { Kejadian } \\
\text { Hiperemesis } \\
\text { Gravidarum }\end{array}$} & \multirow{2}{*}{\multicolumn{2}{|c|}{$\begin{array}{l}\text { Juml } \\
\text { ah }\end{array}$}} & \multirow{3}{*}{$\begin{array}{l}\text { p- } \\
\text { va } \\
\text { lu } \\
\text { e }\end{array}$} \\
\hline & & \multicolumn{2}{|c|}{$\begin{array}{l}\text { Tidak } \\
\text { Hipere } \\
\text { mesis } \\
\text { Gravid } \\
\text { arum }\end{array}$} & \multicolumn{2}{|c|}{$\begin{array}{l}\text { Hipere } \\
\text { mesis } \\
\text { Gravid } \\
\text { arum }\end{array}$} & & & \\
\hline & & $\mathbf{F}$ & $\%$ & $\mathbf{F}$ & $\%$ & $\mathbf{F}$ & $\%$ & \\
\hline \multirow[t]{2}{*}{1} & Tidak & 0 & 0 & 1 & 25 & 1 & 2 & \\
\hline & $\begin{array}{l}\text { Diing } \\
\text { inka } \\
\mathrm{n}\end{array}$ & & & 3 & .0 & 3 & $\begin{array}{l}5 . \\
0\end{array}$ & $\begin{array}{l}0, \\
00\end{array}$ \\
\hline \multirow[t]{2}{*}{2} & Diing & 2 & 48 & 1 & 26 & 3 & 7 & 0 \\
\hline & $\begin{array}{l}\text { inka } \\
\mathrm{n}\end{array}$ & 5 & .1 & 4 & .9 & 9 & $\begin{array}{l}5 . \\
0\end{array}$ & \\
\hline \multirow{2}{*}{\multicolumn{2}{|c|}{ Total }} & 2 & 4 & 2 & 5 & 5 & 1 & \\
\hline & & 5 & $\begin{array}{l}8 . \\
1\end{array}$ & 7 & $\begin{array}{l}1 . \\
9\end{array}$ & 2 & $\begin{array}{l}0 \\
0\end{array}$ & \\
\hline
\end{tabular}

Hasil uji statistik dengan menggunakan uji chi square, diperoleh hasil perhitungan $p$ value $=$ 0,000 $\leq$ 0,05, maka Ha diterima. Kesimpulannya Ada Hubungan kehamilan yang tidak diinginkan dengan kejadian hiperemesis gravidarum pada ibu hamil trimester pertama di Puskesmas Tanjung Pasir Kab. Labuhan Batu Utara.

Tabel 4. Hubungan Tekanan

Pekerjaan Dengan Kejadian Hiperemesis Gravidarum di Puskesmas Tanjung Pasir Kab. Labuhan Batu Utara

\begin{tabular}{|c|c|c|c|c|c|c|c|c|}
\hline \multirow{3}{*}{$\begin{array}{l}\mathbf{N} \\
\mathbf{0}\end{array}$} & \multirow{3}{*}{$\begin{array}{l}\text { Tek } \\
\text { ana } \\
\text { n } \\
\text { Pek } \\
\text { erja } \\
\text { an }\end{array}$} & \multicolumn{4}{|c|}{$\begin{array}{l}\text { Kejadian } \\
\text { Hiperemesis } \\
\text { Gravidarum }\end{array}$} & \multirow{2}{*}{\multicolumn{2}{|c|}{$\begin{array}{l}\text { Juml } \\
\text { ah }\end{array}$}} & \multirow{3}{*}{$\begin{array}{l}\text { p- } \\
\text { va } \\
\text { lu } \\
e\end{array}$} \\
\hline & & \multicolumn{2}{|c|}{$\begin{array}{l}\text { Tidak } \\
\text { Hipere } \\
\text { mesis } \\
\text { Gravid } \\
\text { arum }\end{array}$} & \multicolumn{2}{|c|}{$\begin{array}{l}\text { Hipere } \\
\text { mesis } \\
\text { Gravid } \\
\text { arum }\end{array}$} & & & \\
\hline & & $\mathbf{F}$ & $\%$ & $\mathbf{F}$ & $\%$ & $\mathbf{F}$ & $\%$ & \\
\hline 1 & $\begin{array}{l}\text { Mela } \\
\text { mpa } \\
\text { ui }\end{array}$ & 2 & $\begin{array}{l}3 . \\
8\end{array}$ & $\begin{array}{l}1 \\
4\end{array}$ & $\begin{array}{l}26 \\
.9\end{array}$ & $\begin{array}{l}1 \\
6\end{array}$ & $\begin{array}{l}3 \\
0 . \\
8\end{array}$ & \\
\hline 2 & $\begin{array}{l}\text { Tida } \\
\mathrm{k} \\
\text { Mela } \\
\text { mpa } \\
\text { ui }\end{array}$ & $\begin{array}{l}2 \\
3\end{array}$ & $\begin{array}{l}44 \\
.2\end{array}$ & $\begin{array}{l}1 \\
3\end{array}$ & $\begin{array}{l}25 \\
.0\end{array}$ & $\begin{array}{l}3 \\
1\end{array}$ & $\begin{array}{l}0 \\
6 \\
9 . \\
2\end{array}$ & $\begin{array}{l}0, \\
00 \\
2\end{array}$ \\
\hline & tal & $\begin{array}{l}2 \\
5\end{array}$ & $\begin{array}{l}4 \\
8 . \\
1\end{array}$ & $\begin{array}{l}2 \\
7\end{array}$ & $\begin{array}{l}5 \\
1 . \\
9\end{array}$ & $\begin{array}{l}5 \\
2\end{array}$ & $\begin{array}{l}1 \\
0 \\
0\end{array}$ & \\
\hline
\end{tabular}

Hasil uji statistik dengan menggunakan uji chi square, diperoleh hasil perhitungan $p$ value $=$ $0,002 \leq 0,05$, maka Ha diterima. Kesimpulannya Ada Hubungan tekanan pekerjaan dengan kejadian hiperemesis gravidarum pada ibu hamil trimester pertama di Puskesmas Tanjung Pasir Kab. Labuhan Batu Utara.

Tabel 5. Hubungan Pendapatan

Dengan Kejadian Hiperemesis Gravidarum di Puskesmas

Tanjung Pasir Kab. Labuhan Batu Utara

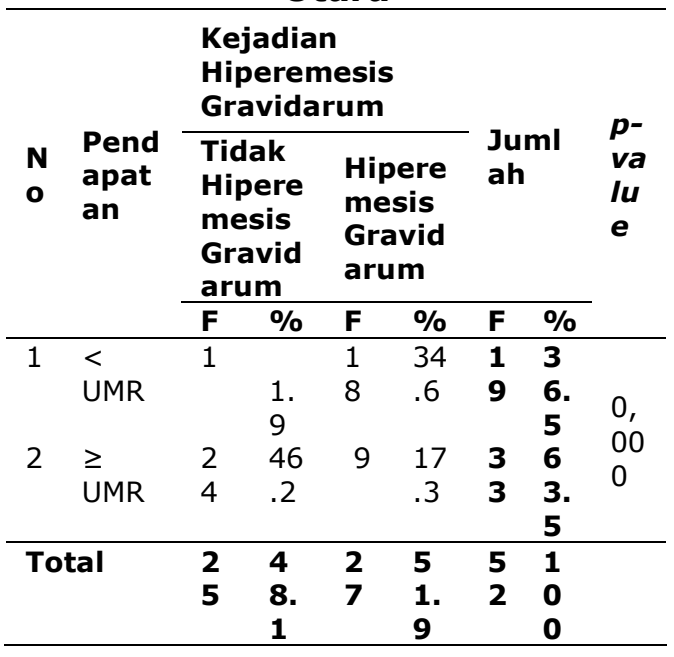

Hasil uji statistik dengan menggunakan uji chi square, diperoleh hasil perhitungan $p$ value $=$ $0,000 \leq 0,05$, maka Ha diterima. Kesimpulannya Ada Hubungan pendapatan dengan kejadian 
hiperemesis gravidarum pada ibu hamil trimester pertama di Puskesmas Tanjung Pasir Kab. Labuhan Batu Utara.

Tabel 6. Hubungan

Keharmonisan Keluarga Dengan Kejadian Hiperemesis Gravidarum di Puskesmas Tanjung Pasir Kab. Labuhan Batu Utara

\begin{tabular}{|c|c|c|c|c|c|c|c|c|}
\hline \multirow{3}{*}{$\begin{array}{l}\mathbf{N} \\
\mathbf{0}\end{array}$} & \multirow{3}{*}{$\begin{array}{l}\text { Kehar } \\
\text { moni } \\
\text { san } \\
\text { Kelua } \\
\text { rga }\end{array}$} & \multicolumn{4}{|c|}{$\begin{array}{l}\text { Kejadian } \\
\text { Hiperemesis } \\
\text { Gravidarum }\end{array}$} & \multirow{2}{*}{\multicolumn{2}{|c|}{$\begin{array}{l}\text { Juml } \\
\text { ah }\end{array}$}} & \\
\hline & & \multicolumn{2}{|c|}{$\begin{array}{l}\text { Tidak } \\
\text { Hiper } \\
\text { emesi } \\
\text { s } \\
\text { Gravid } \\
\text { arum } \\
\end{array}$} & \multicolumn{2}{|c|}{$\begin{array}{l}\text { Hiper } \\
\text { emesi } \\
\text { s } \\
\text { Gravid } \\
\text { arum }\end{array}$} & & & $\begin{array}{l}v \\
a l \\
u \\
e\end{array}$ \\
\hline & & $\mathbf{F}$ & $\%$ & $\mathbf{F}$ & $\%$ & $\mathbf{F}$ & $\%$ & \\
\hline \multirow[t]{2}{*}{1} & Tidak & 2 & & 2 & 40 & 2 & 4 & \\
\hline & $\begin{array}{l}\text { Harmo } \\
\text { nis }\end{array}$ & & $\begin{array}{l}3 . \\
8\end{array}$ & 1 & .4 & 3 & $\begin{array}{l}4 \\
2\end{array}$ & $\begin{array}{l}0, \\
0\end{array}$ \\
\hline \multirow[t]{2}{*}{2} & $\begin{array}{l}\text { Harmo } \\
\text { nis }\end{array}$ & $\begin{array}{l}2 \\
3\end{array}$ & $\begin{array}{l}44 \\
.2\end{array}$ & 6 & $\begin{array}{l}11 \\
.5\end{array}$ & $\begin{array}{l}2 \\
9\end{array}$ & $\begin{array}{l}5 \\
5\end{array}$ & $\begin{array}{l}0 \\
0\end{array}$ \\
\hline & & & & & & & 8 & \\
\hline \multicolumn{2}{|c|}{ Total } & $\begin{array}{l}2 \\
5\end{array}$ & $\begin{array}{l}4 \\
8 . \\
1\end{array}$ & $\begin{array}{l}2 \\
7\end{array}$ & $\begin{array}{l}5 \\
1 . \\
9\end{array}$ & $\begin{array}{l}5 \\
2\end{array}$ & $\begin{array}{l}1 \\
\mathbf{0} \\
\mathbf{0}\end{array}$ & \\
\hline
\end{tabular}

Hasil uji statistik dengan menggunakan uji chi square, diperoleh hasil perhitungan $p$ value $=$ $0,000 \leq 0,05$, maka $\mathrm{Ha}$ diterima. Kesimpulannya Ada Hubungan Keharmonisan Keluarga dengan kejadian hiperemesis gravidarum pada ibu hamil trimester pertama di Puskesmas Tanjung Pasir Kab. Labuhan Batu Utara.

\section{Hubungan Anemia Dengan Kejadian Hiperemesis Gravidarum di Puskesmas Tanjung Pasir Kab. Labuhan Batu Utara}

Kadar hemoglobin pada darah dikatakan anemia apabila kadar $\mathrm{Hb}$ dasar pada pria <13 gr/\%, wanita < 12 gr/\% dan pada ibu hamil < 11 gr/\%. Gangguan kesehatan yang biasa dialami ibu hamil berkisar dua puluh persen, dimana biasanya ibu hamil mengalami kejadian infeksi lebih tinggi di banding dengan ibu hamil dengan nilai hematology normal. Dikatakan anemia bila nilai haemoglobin pada wanita hamil trimester I < $11 \mathrm{gr} / \mathrm{dl}$, trimester II < $10,5 \mathrm{gr} / \mathrm{dl}$ dan trimester III $<10 \mathrm{gr} / \mathrm{dl}$ (Mansjoer, 2006). Sirkulasi darah dalam tubuh ibu selama kehamilan terus meningkat mulai sejak kehamilan berusia 10 minggu dan mencapai puncaknya dalam kehamilan antara 32 dan 36 minggu. Kemudian mulai dari awal kehamilan berusia 8 minggu sampai 40 hari postpartum dan kadar $\mathrm{Hb}$ dalam darah, jumlah eritrosit serta nilai hematokrit, ketiga nilai tersebut terus menurun sampai kehamilan 7 hari postpartum. Setelah itu ketiga nilai meningkat kembali pada 40 hari postpartum atau seperti sebelum terjadi kehamilan. Batas terendah untuk kadar $\mathrm{Hb}$ dalam darah selama masa kehamilan bernilai $10 \mathrm{gr} / \mathrm{dl}$, bila kurang dari itu disebut anemia dalam kehamilan. Menurut data badan kesehatan dunia (WHO) kadar HB ibu selama kehamilan di bagi menjadi tiga klasifikasi yaitu HB kategori Normal (> $11 \mathrm{gr} / \%$ ), HB kategori anemia ringan (9-11 gr/\%) dan HB kategori anemia berat ( $<7 \mathrm{gr} / \%$ ) (Husaini, 2009). Upaya yang dapat dilakukan untuk mengatasi hiperemesis gravidarum adalah dengan menganjurkan ibu untuk selalu mengkonsumsi vitamin, suplemen seperti asam folat agar ibu dapat terhindar dari gejala seperti mual dan muntah yang berlebihan serta menyarankan ibu untuk mengkonsumsi snack ringan seperti roti atau biscuit dan mengubah pola makan sedikit dalam porsi kecil. Adapun tanda - tanda ibu hamil yang mengalami hiperemesis grade 3 adalah suhu tubuh ibu meningkatkan tekanan darah turun (Arisman, 2006). 


\section{Hubungan Gravida Dengan Kejadian Hiperemesis Gravidarum di Puskesmas Tanjung Pasir Kab. Labuhan Batu Utara}

Faktor status gravida mempengaruhi kejadian emesis gravidarum. Pada ibu dengan primigravida, faktor psikologis memegang peranan penting pada penyakit ini, rasa takut yang dialami ibu selama masa kehamilan mengenai tanggung jawab sebagai seorang ibu/istri dapat berdampak pada psikologis ibu yang memperburuk keadaan mual dan muntah semangkin parah sebagai ekspresi dari ibu hamil yang masih merasa takut atau belum siap menjadi seorang ibu (Ansari, 2012). Penyesuaian gejala seperti mual dan muntah akan terus dialami ibu hamil sampai dengan usia kehamilan tiga bulan. Pada ibu yang baru pertama hamil biasa kondisi tubuh belum dapat beradaptasi dengan hormone estrogen dan chorionic gonadotropin yang dapat menyebabkan ibu mengalami mual dan muntah berbeda dengan ibu yang sudah memiliki pengalaman dalam menjalani kehamilan dan melahirkan yang dapat beradaftasi dengan hormone estrogen dan chorionic gonadotropin. Dari hasil penelitian menyatakan bahwa ada hubungan jumlah berapa kali seorang hamil terhadap kejadian hyperemesis gravidarum (Masruroh dan Ikke 2016).

\section{Hubungan Kehamilan Tidak Diinginkan Dengan Kejadian Hiperemesis Gravidarum di Puskesmas Tanjung Pasir Kab. Labuhan Batu Utara}

Trauma pada ibu akan kehamilan sebelumnya akan membawa beban psikologi buat ibu hamil, seperti trauma akan kejadian-kejadian buruk pada saat kehamilan sebelumnya atau merasa cemas yang berlebihan karena pada kehamilan tiga bulan pertama kondisi fisik ibu yang sedang mengalami penyesuaian pertumbuhan janin dalam kandungan. Beban yang selalu dialami seorang istri misalnya masih belum mendapatkan tempat tinggal yang layak atau masih satu rumah dengan keluarga yang lain, ataupun kekhawatiran ibu akan kebutuhan ekonomi yang belum memadai. Selain itu faktor kelelahan karena merawat anak yang masih usia 6 bulan juga menyebabkan stres bagi ibu hamil. Mental emosional ibu yang tidak baik akan terus berpengaruh terhadap kejadian hyperemesis gravidarum ibu (Syamsuddin, Lestari and Fachlevy, 2018) menyatakan bahwa ada hubungan signifikan antara variable psikologis ibu hamil dengan hyperemesis gravidarum. RSUD $\mathrm{H}$. Abd. Manan Simatupang Kisaran tahun 2017.

\section{Hubungan Tekanan Pekerjaan Dengan Kejadian Hiperemesis Gravidarum di Puskesmas Tanjung Pasir Kab. Labuhan Batu Utara}

Harapan lain dari Ibu hamil dalam penelitian ini adalah agar tidak diganggu pada saat mual, namun ada pula yang justru ingin ditemani saat mengalami mual muntah. Harapan ini membutuhkan dukungan emosional dari suami maupun keluarga. Menurut (Bobak, Bowden and Jones, 2015) dukungan emosional yang dapat diberikan kepada ibu hamil dapat berupa pemberian perhatian ketika mengalami gangguan seperti mual muntah, mendengarkan keluhan terkait gangguan yang dirasakan serta memberitahu anggota keluarga lain agar tetap memberikan dukungan sehingga ibu hamil merasa diperhatikan.

Hambatan lain adalah masalah psikis 
karena harus hidup bersama mertua ataupun karena ketakutan hamil pertama pada usia tua. Rasa tidak nyaman dapat menimbulkan stress bagi ibu hamil. Menurut (Wijakjosatro , 2014) ada hubungan bermakna antara stres dengan sindrom hiperemesis gravidarum. Dalam mengatasi hambatan ini bidan dapat mengadakan pendekatan ke klien dan keluarga untuk memberi dukungan kepada ibu hamil. Hasil penelitian (Safarwati, 2016) dapat disimpulkan bahwa ada hubungan yang siqnifikan variable dukungan suami dengan kejadian hiperemesis gravidarum. Selain itu bidan juga dapat memberi sanjungan untuk membesarkan hati ibu hamil. Dengan sanjungan tersebut kepercayaan diri ibu hamil dapat meningkat sehingga memiliki semangat dalam menjalani kehamilannya dan mampu mengatasi keluhan yang dirasakan.

Hubungan Pendapatan Dengan Kejadian Hiperemesis Gravidarum di Puskesmas Tanjung Pasir Kab. Labuhan Batu Utara

Menurut pendapat peneliti, sosial ekonomi merupakan salah satu faktor yang mempengaruhi kejadian hyperemesis gravidarum. Status sosial ekonomi yang rendah akan mempengaruhi ibu hamil terkena anemia. Disamping penghasilan yang diperoleh keluarga dalam memenuhi kebutuhan masih belum tercukupi ibu hamil juga di haruskan memeriksakan kehamilan kefasilitas kesehatan untuk mendetektisi apakah kehamilannya baik baik saja atau mengalami komplikasi yang membutuhkan biaya relative mahal. Di karenakan biaya yang tidak memadai tak jarang ibu hamil tidak melakukan pemeriksaan kehamilannya sehingga sehingga kemungkinan besar tanda dan gejalagejala mual dan muntah (hyperemesis gravidarum) tidak terdeteksi.

Hubungan
Keluarga Deharmonisan
Hiperemesis Granidarum Kejadian
Puskesmas Tanjung Pasir Kab.
Labuhan Batu Utara

Dukungan suami selama masa ibu hamil akan membuatnya merasa nyaman dan terjadi emosinya. Ibu dapat menjalani masa kehamilannya dengan baik. Pendamping ibu yang paling dekat adalah suami sehingga suami harus bisa memberikan dukungan atau motivasi kepada ibu untuk selalu menjaga kandungan agar tetap sehat. Pikiran positif harus selalu dikembangkan oleh ibu dan selalu di support oleh suami. Suami harus bisa berkata tidak kasar dan berikan pujian dan dukungan bila istri sedang menghadapi masalah masalah sulit saat hamil. Suami juga harus tau perkembangan calon bayi dalam kandungan, memperhatikan kebutuhan makan, minum dan istirahat istri. Menyempatkan untuk lebih sering berdua misalnya, jalan pagi, makan berdua, melakukan pemeriksaan kehamilan berdua dan rekreasi bersama. Sikap positif dan dukungan yang baik dari suami akan membuat proses kehamilan berjalan dengan baik dan menyenangkan serta kondisi janin pun sehat dan kuat (Nurdiansyah, 2015).

Dukungan suami akan membantu ibu dalam mengurangi rasa cemas, bingung dan takut sehingga ibu dapat menjalani kehamilannya dengan perasaan lebih tenang dan nyaman. Suami dapat memberikan dukungan seperti mengantar ibu memeriksakan kehamilannya, mengingatkan ibu meminum tablet zat besi, membantu melakukan kegiatan rumah tangga dan member pijatan bila istri merasa lelah. Walaupun suami melakukan tindakan kecil, tindakan tersebut 
mempunyai makna yang berarti dalam meningkatkan kesehatan psikologis ibu hamil.

\section{KESIMPULAN}

Kesimpulan penelitian ini ada Hubungan faktor psikologis dengan kejadian hiperemesis gravidarum pada ibu hamil trimester pertama di Wilayah Puskesmas Tanjung Pasir. Disarankan kepada responden hendaknya meningkatkan pengetahuan tentang cara pencegahan dan mengatasi hiperemesis gravidarum.

\section{DAFTAR PUSTAKA}

Arisman, 2006. Gizi Dalam Daur Kehidupan. EGC : Jakarta

Asuhan Persalinan Normal Revisi, 2017. Bentuk-bentuk Dukungan Suami Asuhan Esensi Persalinan, Jakarta: Yayasan Bina Pustaka Sarwono Prawirohardjo, JNPK-KR/POGI.

Bobak, Irene. 2015. Buku Ajar KeperawatanMaternitasedisi 4, Jakarta:EGC

Elsa V, Pertiwi HW. Hubungan paritas ibu hamil trimester I dengan kejadian emesis gravidarum di puskesmas Teras. 2012;2:(dikutip 2017 November 02). 44-46p.

Husaini. 2009. Manajemen: Teori, praktik dan Riset Pendidikan. Jakarta: Bumi aksara

Intyaswati. Gambaran penanganan mandiri ibu hamil dengan emesis gravidarum pada trimester I di BKIA Rumah Sakit William Booth Surabaya. 2012; (dikutip 2017 Oktober 29). 5-6p.

Masruroh, Retnosari I. Hubungan antara umur ibu dan gravida dengan kejadian hiperemesis gravidarum di RSUD Ambarawa kabupaten Semarang. Jurnal : Fakultas Kebidanan Universitas Ngudi Waluyo. 2016; (dikutip 2017 Mar 19). 204,205,207,208 p. Diunduh dari: https://ppnijateng.org/wp.cont ent/uploads/

2016/11/prosiding.muswil.II.ip emi.jateng.magelang.17.septe mbe r.2016.215.222.pdf

Prawirohardjo, 2017. Ilmu Kebidanan, Jakarta, Yayasan Bina Pustaka Sarwono Prawirohardjo

Saifuddin, Dkk. 2015. Jenis-jenis Hiperemesis Gravidarum Buku Asuhan Nasional Pelayanan Kesehatan Maternal.

Saifuddin, A. B. 2016, Gejala Hiperemesis Gravidarum Buku Panduan Praktik Pelayanan Kontrasepsi, Edisi 2, Jakarta: Yayasan Bina Putaka Sarwono Prawirohardjo.

Salman,dkk. 2016. Asuhan Kebidanan Anternatal. Jakarta:EGC

Suwardi, Suyanti, 2019. Hubungan Paritas, Dukungan Suami Dan Dukungan Keluarga Pada Ibu Hamil Dengan Hiperemesis Gravidarum; Jurnal Ilmiah IImu Kesehatan: Wawasan Kesehatan, Vol.2, No.5

Tiran D. Pendekatan pada kehamilan. Didalam: Mual dan muntah kehamilan. Jakarta: EGC; 2009. $1,5,15,20,287 \mathrm{p}$. 